\title{
Vanadium hyper-enrichments in marine organic-rich mudrocks
}

\author{
B. KENDALL ${ }^{1 *}$, A. KUNERT ${ }^{1}$, S. YANG ${ }^{1}$
}

${ }^{1}$ University of Waterloo, Waterloo, ON, Canada

(correspondence: *bkendall@uwaterloo.ca)

Vanadium hyper-enrichments ( $>500 \mu \mathrm{g} / \mathrm{g}$ ) occur in many Ediacaran and Phanerozoic organic-rich mudrocks [1] but not in organic-rich sediments from modern anoxic basins. It was proposed that V hyper-enrichments in the Upper Devonian to Lower Mississippian Bakken Formation required hypersulfidic conditions (dissolved $\mathrm{H}_{2} \mathrm{~S}>10 \mathrm{mM}$ ) in the bottom waters or sediment pore fluids of a shallow epicontinental sea [2]. However, geochemical indicators for local depositional conditions (sedimentary Fe speciation, paleosalinity proxies, Mo versus $U$ enrichments, Mo isotope data and/or $U$ isotope data) for other organic-rich mudrock units in epicontinental seas and along continental margins suggest that a large flux of sinking Fe-Mn (oxyhydr)oxide particulates can deliver large amounts of $\mathrm{V}$ to euxinic or non-euxinic (with sulfidic pore fluids) seafloor and cause $\mathrm{V}$ hyper-enrichments $[3,4]$.

We report additional examples of $\mathrm{V}$ hyper-enrichments in the Upper Devonian to Lower Mississippian Exshaw Formation (Alberta) and Jurassic Gordondale Member (Fernie Formation, British Columbia). Many samples from the Exshaw Formation, deposited in an epicontinental sea, have V hyper-enrichments (up to $1460 \mu \mathrm{g} / \mathrm{g}$ ), variable Mo $(18-129 \mu \mathrm{g} / \mathrm{g})$ enrichments and Mo-U enrichment covariation patterns that suggest a pronounced flux of Fe-Mn particulates to sediments overlain by both non-euxinic and euxinic bottom waters. Low $\delta^{98} \mathrm{Mo}$ in samples with $\mathrm{V}$ hyper-enrichments suggest delivery of isotopically light Mo to sediments by FeMn particulates. By contrast, the Gordondale Member has V hyper-enrichments (up to $2757 \mu \mathrm{g} / \mathrm{g}$ ), high Mo enrichments (commonly $>100 \mu \mathrm{g} / \mathrm{g} \mathrm{Mo}$ ), and Mo-U and Cd-Mo enrichment covariation patterns that collectively point to deposition of euxinic sediments in a minimally restricted, high-productivity, continental margin setting without clear evidence of a pronounced Fe-Mn particulate flux. It is unlikely hypersulfidic conditions developed on this minimally restricted continental margin, but nevertheless this setting likely records more intense euxinic conditions than modern oxygen minimum zones and their less V-enriched sediments. We conclude $\mathrm{V}$ hyper-enrichments in organic-rich mudrocks can occur in a range of depositional environments from shallow epicontinental seas to euxinic continental margins.

[1] Sahoo et al. (2012) Nature 489, 546-549. [2] Scott et al. (2017) Chem Geol 452, 24-33. [3] Ostrander et al. (2019) $G C A$ 261, 191-209. [4] Kendall et al. (in press) GCA. 